\title{
Correction to: Exploring the oxygenase function of Form II Rubisco for production of glycolate from $\mathrm{CO}_{2}$
}

Fan Yang ${ }^{1,2,3}$, Junli Zhang ${ }^{1,2,3}$, Zhen Cai ${ }^{1}$, Jie Zhou ${ }^{1,3^{*}}$ and Yin $\mathrm{Li}^{1^{*}}$

\section{Correction to: AMB Expr (2021) 11:65}

https://doi.org/10.1186/s13568-021-01224-6

Following publication of the original article (Yang et al. 2021), the authors would like to correct the sentences in Abstract and Discussion sections. The corrections are listed below:

In Abstract section, the following sentence should be removed, "This is also the highest glycolate titer biotechnologically produced from $\mathrm{CO}_{2}$ ".

In Discussion section, the corrected third paragraph follows:

Additionally, inactivation of glycolate metabolism was reported to render a high- $\mathrm{CO}_{2}$-requiring (HCR) phenotype which means the mutant was not able to grow at ambient $\mathrm{CO}_{2}$ level (Eisenhut et al. 2008a, b). This HCR phenotype was presumably ascribed to the intracellular accumulation of toxic amounts of glycolate (Eisenhut et al. 2008a, b). It was reported that the intracellular glycolate concentration in the mutant increased to a much higher level within a few hours after the mutant was transferred from $\mathrm{HC}\left(5 \% \mathrm{CO}_{2}\right)$ to $\mathrm{LC}$ (air, $0.035 \% \mathrm{CO}_{2}$ ) condition (Eisenhut et al. 2008a, b). Interestingly, strain WT- $\Delta$ glcD that we constructed did not exhibit the HCR

The original article can be found online at https://doi.org/10.1186/s13568021-01224-6.

\footnotetext{
*Correspondence: jiezhouw@im.ac.cn; yli@im.ac.cn

${ }^{1}$ CAS Key Laboratory of Microbial Physiological and Metabolic Engineering, State Key Laboratory of Microbial Resources, Institute of Microbiology, Chinese Academy of Sciences, Beijing 100101, China

${ }^{3}$ CAS Key Laboratory of Microbial Physiological and Metabolic Engineering, State Key Laboratory of Transducer Technology, Institute of Microbiology, Chinese Academy of Sciences, Beijing 100101, China Full list of author information is available at the end of the article
}

phenotype (Additional file 1: Fig. S3). Further investigation suggested that strain WT- $\Delta$ glcD did accumulate intracellular glycolate, but more than $99 \%$ of glycolate was excreted to the culture (Fig. 2 and Additional file 1: Fig. S2). Glycolate excretion was previously observed in some filamentous cyanobacterial strains and green alga like Chlamydomonas (Eisenhut et al. 2006; Günther et al. 2012, 2018). It is reported that Chlamydomonas could be forced to produce and excrete glycolate constantly without negative impact on cell vitality under specific conditions (Günther et al. 2012; Taubert et al. 2019). A glycolate titer of $3.1 \mathrm{~g} / \mathrm{L}$ within 21 days was achieved by the aeration of a mixture of $40 \% \mathrm{O}_{2} / 0.2 \% \mathrm{CO}_{2}$ and by the addition of EZA (6-Ethoxy-2-benzothiazolesulfonamide), an efficient inhibitor for both CCMs and the GlyDH (glycolate dehydrogenase) in C2 cycle (Taubert et al. 2019). However, glycolate excretion was not observed in Synechocystis, nor in mutant with HCR phenotype (Eisenhut et al. 2006, 2008a, b). It is likely that glycolate excretion of strain WT- $\Delta$ glcD helped maintain the intracellular glycolate concentration at a low level, which allows the cell to grow normally at ambient $\mathrm{CO}_{2}$ level, without displaying the HCR phenotype. It is worthy to further investigate the underlying mechanism of glycolate excretion of strain WT- $\Delta$ glcD. (c) The Author(s) 2021. Open Access This article is licensed under a Creative Commons Attribution 4.0 International License, which permits use, sharing, adaptation, distribution and reproduction in any medium or format, as long as you give appropriate credit to the original author(s) and the source, provide a link to the Creative Commons licence, and indicate if changes were made. The images or other third party material in this article are included in the article's Creative Commons licence, unless indicated otherwise in a credit line to the material. If material is not included in the article's Creative Commons licence and your intended use is not permitted by statutory regulation or exceeds the permitted use, you will need to obtain permission directly from the copyright holder. To view a copy of this licence, visit http://creativecommons.org/licenses/by/4.0/. 


\section{Author details}

${ }^{1}$ CAS Key Laboratory of Microbial Physiological and Metabolic Engineering, State Key Laboratory of Microbial Resources, Institute of Microbiology, Chinese Academy of Sciences, Beijing 100101, China. ${ }^{2}$ University of the Chinese Academy of Sciences, Beijing, China. ${ }^{3}$ CAS Key Laboratory of Microbial Physiological and Metabolic Engineering, State Key Laboratory of Transducer Technology, Institute of Microbiology, Chinese Academy of Sciences, Beijing 100101, China.

Published online: 24 September 2021

\section{References}

Eisenhut M, Kahlon S, Hasse D, Ewald R, Lieman-Hurwitz J, Ogawa T, Ruth W, Bauwe H, Kaplan A, Hagemann M (2006) The plant-like C2 glycolate cycle and the bacterial-like glycerate pathway cooperate in phosphoglycolate metabolism in cyanobacteria. Plant Physiol 142(1):333-342. https://doi. org/10.1104/pp.106.082982

Eisenhut M, Huege J, Schwarz D, Bauwe H, Kopka J, Hagemann M (2008a) Metabolome phenotyping of inorganic carbon limitation in cells of the wild type and photorespiratory mutants of the cyanobacterium Synechocystis sp. strain PCC 6803. Plant Physiol 148(4):2109-2120. https://doi.org/ 10.1104/pp.108.129403

Eisenhut M, Ruth W, Haimovich M, Bauwe H, Kaplan A, Hagemann M (2008b) The photorespiratory glycolate metabolism is essential for cyanobacteria and might have been conveyed endosymbiontically to plants. Proc Natl Acad Sci U S A 105(44):17199-17204. https://doi.org/10.1073/pnas.08070 43105

Günther A, Jakob T, Goss R, König S, Spindler D, Räbiger N, John S, Heithoff S, Fresewinkel M, Posten C, Wilhelm C (2012) Methane production from glycolate excreting algae as a new concept in the production of biofuels. Bioresour Technol 121:454-457. https://doi.org/10.1016/j.biortech.2012. 06.120

Günther S, Becker D, Hübschmann T, Reinert S, Kleinsteuber S, Müller S, Wilhelm C (2018) Long-term biogas production from glycolate by diverse and highly dynamic communities. Microorganisms 6(4):103-121. https:// doi.org/10.3390/microorganisms6040103

Taubert A, Jakob T, Wilhelm C (2019) Glycolate from microalgae: an efficient carbon source for biotechnological applications. Plant Biotechnol J 17(8):1538-1546. https://doi.org/10.1111/pbi.13078

Yang F, Zhang J, Cai Z, Zhou J, Li Y (2021) Exploring the oxygenase function of Form II Rubisco for production of glycolate from $\mathrm{CO}_{2}$. AMB Expr 11:65. https://doi.org/10.1186/s13568-021-01224-6

\section{Publisher's Note}

Springer Nature remains neutral with regard to jurisdictional claims in published maps and institutional affiliations.

\section{Submit your manuscript to a SpringerOpen ${ }^{\circ}$ journal and benefit from:}

- Convenient online submission

- Rigorous peer review

- Open access: articles freely available online

- High visibility within the field

- Retaining the copyright to your article

Submit your next manuscript at $\boldsymbol{\nabla}$ springeropen.com 